\title{
Industrial Policy and Vulnerable Capitalism ${ }^{1}$
}

\section{David Bailey and Keith Cowling*}

*Institute for Economic Development Policy, Birmingham Business School, and University of Warwick, respectively, and DARE (Democratic Communities in Academic Research on Economic Development).

\begin{abstract}
This paper emphasises the linkages between corporate strategy, the macroeconomy and the role of industrial policy in this macropolicy context. Whilst this is an aspect of industrial policy which is rarely addressed, we suggest that there is, in fact, a real and highly significant complementarity, especially in the context of modern capitalism, with its distinctive features. The underlying premise is that problems cannot be resolved easily directly at the macro level: appropriate industrial policy may be a necessary ingredient in securing better economic performance. Current discussions of exchange rate policies and the major adjustments required for eliminating external imbalances between the United States, China, Japan and Europe would seem to point to this conclusion. This paper emphasises the linkage between corporate strategy, the macroeconomy and the role of industrial policy in this macropolicy context, and points to appropriate policies that aim to rebalance the economy by shifting towards a more diffuse governance structure that deconcentrates strategic decision making and opens up the potential for new forces of dynamism.
\end{abstract}

\section{$1 \quad$ Introduction}

In 1932, Aldeous Huxley warned against a future in which happiness was a matter of consuming mass-produced goods along with lots of soma, a drug created for delivering pleasure. Over seventy years on, psychiatrists and neuro-scientists such as Wybrow (2005) portray a society in the US that is not very far-removed from Huxley's Brave New World, and one which they liken to a mental patient addicted to mass consumption at the expense of relationships with other people. ${ }^{2}$ To pay for this increased consumption, Americans have had to work longer hours, which has produced a 'paradox of prosperity' in that Americans seem too busy to enjoy the

\footnotetext{
${ }^{1}$ An earlier version of this paper was presented at the L'Institute Graduate Network Workshop in Bath in 2005. We are grateful to participants for comments and suggestions, and most especially Dan Coffey.

${ }^{2}$ As Galbraith (1958) observed, advertising provides a powerful instrument for creating wants by creating psychological dependency
} 
extra goods and services that they consume (The New York Times, 2005). ${ }^{3}$ Leaving aside the lack of happiness this has produced ${ }^{4}$, this paper traces the links between increased advertising by US corporations under modern capitalism, falling personal savings, longer hours worked and a rising trade deficit. It suggests that the decisions of elites in giant corporations to engage in extensive advertising and marketing in an attempt to overcome the Schumpeterian limits to the growth of the capitalist system has actually fuelled a type of dynamism, in terms of overall growth and the take up of information and communication technology (ICT) in service industries which has boosted productivity, but has come at a cost in terms of longer hours worked, falling savings and a rising trade deficit. Such dynamism is therefore vulnerable or flawed in that the internal and external imbalances that are building up are increasingly recognised as unsustainable by many commentators. The latter, however, fail to appreciate that these macro-level imbalances cannot be rectified without recognising the role of corporations in modern capitalism and the decisions made by elites, a situation that we characterise as a form of strategic failure. The latter is a situation that occurs when strategic decisions (on key economic variables) are taken by corporate hierarchies, whose interests conflict with the wider public interest (Cowling and Sugden, 1994). Rather, it is argued that a rebalancing of the economy not only requires crucial macro-economic changes to reduce imbalances, but also an industrial policy that tackles this concentration of strategic decision-making in giant firms.

This paper therefore emphasises the linkage between corporate strategy, the macroeconomy and the role of industrial policy in this macropolicy context. Whilst this is an aspect of industrial policy which is rarely addressed, we suggest that there is a real complementarity, especially in the context of modern capitalism, with its distinctive features. The underlying premise is that problems cannot be resolved easily directly at the macro level; appropriate industrial policy may be a necessary ingredient in securing better economic performance. Current discussions of

\footnotetext{
${ }^{3}$ Cowling (2006) looks at this paradoxical situation in more detail, where research suggests that life satisfaction declines as work hours increase, yet US workers are working longer hours. He argues that more intensive advertising in the US may drive such trends in that it can push people away from their underlying (or meta) preferences towards longer hours worked and less saving. ${ }^{4}$ Wybrow (2005) points to US government figures that show that $30 \%$ of US citizens are anxious, double the figure of a decade earlier. On happiness and work-life balance, see Blanchflower and Oswald (2004) who found that the US has the greatest problems with work-life balance.
} 
exchange rate policies and the major adjustments required for eliminating external imbalances between the United States, China, Japan and Europe would seem to point to this conclusion.

\section{Rivalry and Advertising under Modern Capitalism}

Modern capitalism is characterised by large dominant corporations in active rivalry with each other, in the context of oligopolistic markets. We observe such markets wherever we look, and whilst many other production units exist in industrial economies, these 'firms' exist under the strategic ambit of the small number of dominant corporations; their autonomy is more apparent than real. The long-run aim of dominant firms is the effective monopolisation of specific industries through organic growth, merger or effective coordination with rivals. Somewhat paradoxically, rivalry and collusion coexist in such concentrated markets, with the 'tit-for tat' strategy providing a useful interpretation of such behaviour, on the one hand eliciting and rewarding cooperation and on the other providing speedy retaliation (but also forgiveness) for non-cooperation (Cowling and Tomlinson, 2005). Rivalry or 'competitive behaviour' is then diverted away from price competition towards product and advertising competition, with corporations induced to invest in the market as well as production. A key feature of such rivalry is investment in advertising, the retailing network and product innovation. This is an attractive alternative for corporations to competing directly on price, and has an additional advantage for oligopolistic firms in that it will take time for rivals to respond, which in turn allows monopoly profits to be made in the meantime. Whilst market share can be gained by such firms, it also enables an extension of the market, beyond its current limits, thereby reducing competition. Overall, advertising should be seen as a characteristic of corporate power, and in turn sustains and enhances such power. ${ }^{5}$

Two recent examples illustrate such behaviour. Gillette (purchased by Procter and Gamble (P\&G) in 2005 for $\$ 57 \mathrm{bn}$, thereby forming the world's biggest consumer products company) has actively sought to expand its market in a number of ways, for

\footnotetext{
${ }^{5}$ For example, in terms of providing the excess capacity to deter entry. Through interview work, Smiley (1998) found investment in advertising, R\&D, brand proliferation and distribution as the key dimensions of capacity for strategic managers in US industry.
} 
example by marketing shaving products to women in the 1990s, and more recently marketing extra blades for its razor (Financial Times, 01/02/05). Indeed, P\&G is the top advertising spender in the US, spending some \$2.9bn in 2004 alone (TNS, 2005). ${ }^{6}$ Another example is the pharmaceutical industry. While 'big pharma' corporations are routinely praised for investing substantial amounts in $R \& D$ compared to other industries (and have thereby been 'rewarded' by governments with extended patent-life protection), this represents only a half of what they spend on marketing and distribution (The Observer, 21/03/04). For such reasons, Bailey et al (1994) characterised firms such as Glaxo as 'market driven rather than research led'. Whilst direct firm-to-consumer advertising by pharmaceutical firms is legal in the US, it is prohibited in other countries such as Britain, but this has not stopped such firms attempting to raise awareness of medical conditions through advertising in order to grow the market and thereby create a new demand for the drugs they have developed (The Daily Telegraph, 12/11/04). ${ }^{7}$

More generally, if the capitalist system is prone to recession or depression, corporations will seek to ward off the implications for themselves, by such means (although it should be noted that this is an imperfect method, in that advertising is itself cyclical). We thus see very large expenditures by the major US corporations, with the top ten spenders alone in the US collectively spending some \$18bn in 2004 on advertising (TNS, 2005). ${ }^{8}$ Such behaviour has led to a substantial surge in investment aimed at shaping and extending the market: in 1998 R\&D as a proportion of GDP was $2.7 \%$ while advertising was 2.4\% (Euromonitor, 1999; OECD, 1999). ${ }^{9}$ Not surprisingly, modern capitalism is characterised by an increasing proportion of market investment to total investment. This is a particular feature of the most advanced capitalist economies, notably the United States. Over the period 1919 to 1976, advertising expenditure per person in the US rose 150\% (Brack and Cowling,

\footnotetext{
${ }^{6}$ In contrast, P\&G reduced R\&D expenditure by 20\% over 2001-2004 (Business Week, 11/10/04).

7 The House of Commons (2005) has been concerned over the growing influence of the large pharmaceutical firms, suggesting that "the heart of the problem may be the trend for the industry to become ever more driven by its marketing force". It has called for greater restrictions to be placed on medicines promotion by such firms.

${ }^{8}$ As noted, in 2004 Proctor and Gamble spent $\$ 2.9 \mathrm{bn}$ on advertising in the US alone, and was followed by General Motors (\$2.8bn), Time Warner (\$2bn), SBC (\$2bn), DaimlerChrysler (\$1.8bn), and Ford (\$1.6bn) (TNS, 2005).

${ }^{9}$ It should be noted that R\&D includes public investment and is seen as the most dynamic element of investment
} 
1983), while more recently Cowling and Poolsombat (2005) cite evidence showing a sevenfold increase in total advertising expenditure in the US over the period 1945 2005, or a four-fold increase per capita when the growth in the US population is factored in. During the 1990s, total advertising expenditure in current prices is estimated to have grown from just under $\$ 130 \mathrm{bn}$ in 1990 to $\$ 215 \mathrm{bn}$ in 1999 (US Census Bureau, 2000). In addition, from the 1990s onwards we have witnessed the rapid expansion of internet advertising which has only partly substituted for other media, but rather has fuelled further overall advertising growth (ZenithOptimedia, 2006) and has not necessarily led to lower prices for consumers. ${ }^{10}$ Given such growth, Li (2003) estimated total advertising expenditure in the US in 2001 to be as high as $\$ 233 \mathrm{bn}$. On a more narrow definition of 'major media' advertising, North American advertising expenditures grew from $\$ 158 \mathrm{bn}$ in 2003 to a projected $\$ 192 \mathrm{bn}$ in 2007, with North America accounting for $42 \%$ of global advertising expenditures (ZenithOptimedia, 2006). We would expect that globalisation will tend to lead to economies converging over time, but for now huge gaps remain, with the US far ahead of other economies in its investment on advertising, being ten times that in France (European Audiovisual Observatory, in Cowling and Poolsombat, 2005).

\section{Impact: Growing and Unsustainable Imbalances}

This pressure of advertising and continual new product innovation can be expected to induce a higher level of consumption out of current income. This works by creating continuing dissatisfaction with present consumption, with wants being created and sustained. ${ }^{11}$ While there has been limited exploration of the impact of advertising on the macro-economy (as few economists have seen it as significant), where such work has been undertaken it has found advertising to have a significant positive impact on propensities to consume (see Taylor and Weiserbs, 1972). The rising levels of advertising expenditure through the twentieth century noted above will have thus increased levels of private consumption at the expense of savings.

\footnotetext{
${ }_{10}$ Daripa and Kapur (2001) argued that the tendency for e-commerce to increase price competition was overstated and that industrial structures may become more concentrated in online markets.

${ }^{11}$ It can also been seen as shifting preferences in favour of private consumption rather than public consumption, and perhaps reduces the willingness of citizens to 'pay' for the latter through taxation. This in turn may put a limit on what is seen as the 'legitimate' extent of government activity.
} 
In so doing, increased advertising exacerbates short-termist pressures in capitalism, in that present needs become more pressing, and making allowance for future needs can be postponed. As people procrastinate, we observe low levels of saving and pension crises. Whilst affecting several economies, this is again most acutely observed in the United States. Here, there has been a low propensity for households to save, with saving only taking place to finance consumption of household durables (Ruggles, 1993). Furthermore, the debt levels of US households have grown considerably over the last thirty years, despite the US government creating some twenty tax breaks to encourage savings since 1974. As Mishel and Eisenbrey (2005) detail, drawing on official US figures, the indebtedness of US households, after adjusting for inflation, rose over 35\% over the period 2001-2005, leaving the level of debt as a percentage of after-tax income at the highest level since US economic records began. The US household debt-service ratio (the percent of after-tax income that goes to pay off debts) is also at an all-time high of $13.6 \%$. Americans are increasingly dependent on borrowed money, with the percentage of spending covered by wages and salaries having fallen from $78 \%$ in 1980 to $71 \%$ in 1990 and to $64 \%$ by January 2006 (Capital, 05/03/06). Not surprisingly, the personal savings rate, which ran at around $10 \%$ of disposable income from 1974 to 1984 , had fallen to around $5 \%$ by 1994 , and was negative throughout 2005 , for the first time in post-war US history. By January 2006, the personal savings rate had deteriorated to minus $0.7 \%$ (ibid). $^{12}$

But the impact of modern corporations' rivalry through advertising does not end with a rise in consumption expenditure and a fall in savings at the macro level. The income constraint on consumption can be removed by appropriate adjustments in the labour supply, which can be seen as endogenous to corporate power. In other words, with the work-leisure choice determined by artificial 'created' preferences, we

${ }^{12}$ Some have suggested that the personal savings statistics in the United States are artificially low. Nordhaus, for example, in testimony to the US Congress in 2002, suggested that if assets such as real estate and equities were included in the savings figures, the savings rate in the 1990s would be as high as $25 \%$. Yoo (1998) examined the effect of adding in changes in the value of households' assets (notably the rise in equity prices). This broader measure of 'savings' was found by Yoo to be both higher and more volatile than the personal savings rate, as one would expect. Of key relevance here, though, is that it had little impact on how trends in savings should be viewed; Yoo found that this alternative savings measure also showed a declining savings rate over 1980-1995, in spite of rising equity prices. 
can expect a link between the intensity of advertising and hours of work, both per week and in terms of participation rates, with people encouraged to offer a larger fraction of their time to the generation of private income for private consumption. ${ }^{13}$ Again, although there has been limited work on the link between advertising and the labour supply, this is exactly what we find. Brack and Cowling (1983) found that the length of the work year for labour in US manufacturing was strongly influenced by advertising intensity, with an elasticity of 0.18 over the period 1919 to 1976 . Put another way, advertising had the effect of increasing the working year in the US by $27 \%$ over the period. This work on the United States has been updated and extended by Cowling and Poolsombat (2005), whose results demonstrate the possibility that "high observed hours of work was the result of a desire by workers to work longer due to a shift in their preferences from leisure to increased consumption, caused by the huge increase in advertising". Similar effects have been found for Britain over the period 1952 to 1997: Fraser and Paton (2003) found advertising to be positively associated with hours worked for both males and females. They reach the same conclusion, linking longer hours worked with a "shift in preferences from leisure to increased consumption, caused by the huge increase in mass media advertising".

It is a highly salient characteristic of the United States that hours of work are now much higher than in Europe: Americans work around 50\% more than do the Germans, French and Italians (Prescott, 2004). As with savings, which have been declining over time, this desire by Americans to work longer hours has been increasing relative to other countries over time. In the early 1970s, West Europeans actually worked more than Americans, but by 1994, however, Americans averaged 20\% more work time than adult Germans (Bell and Freeman, 2001). Whilst Europeans have reduced their hours of work over time as productivity has risen, US workers have at least maintained, if not increased, theirs. Bell and Freeman noted that standard labour supply analyses were unable to explain such shifts and suggested that high rewards to success combined with a low social safely net and the lack of job security in the US explained such long hours. Drawing on Cowling and Poolsombat (2005), we would stress another causal factor, namely the rapid

\footnotetext{
${ }^{13}$ It was Duesenberry (1967) who asked "why do people spend so much of their time at work?"
} 
increase in advertising expenditure fuelling rising consumption expenditure and a desire by Americans to work longer in order to consume more. This would imply another area of corporate control over the economy, with a labour force more pliable to corporate interests and, coming back to Huxley's gloomy vision, more compliant and less likely to rebel.

On the external side, the rise in consumption and reduction in savings have contributed to the creation of a huge current account deficit, with the US currently absorbing $70 \%$ of the current account surpluses of the rest of the World (largely China and Japan). ${ }^{14}$ The global economy is seen as increasingly vulnerable to these imbalances (Obstfeld and Rogoff, 2004; IMF, 2006). With a current account deficit of $6 \%$ of GDP, the potential risks in terms of a collapse of the dollar have grown considerably larger in recent years. In this regard, Obstfeld and Rogoff see the current trajectory as "particularly precarious", seeing close parallels with the 1970s, when the Bretton Woods system collapsed. They also stress that an easy rebalancing without pain is more difficult to achieve in the context of a current account deficit which adds up to $20 \%$ of US traded goods production. ${ }^{15}$ Interestingly, Al-Eyd et al (2005) make the critical point that a sustained adjustment in the US current account deficit cannot be achieved through a temporary nominal depreciation of the dollar alone, but also requires a number of other actions to redress government and household imbalances in the United States and to increase national savings (El-Ayd, 2005). They are especially concerned by the falls in US savings, inflows of foreign savings and levels of investment as well as rising consumption.

\footnotetext{
${ }^{14}$ Chinese holdings of dollar denominated assets reached over $\$ 800$ billion at the start of 2006 , while the US trade deficit with China rose to over $\$ 200$ billion in 2005 . This is in line with projections by Bonner and Wiggin (2005) who argued that the US cannot stop itself going further into debt through such high levels of expenditure. In so doing, they drew parallels between the US and the last days of the Roman Empire. In contrast, Bernancke (2005) claimed that the problem is a global savings glut rather than a US savings shortfall, but this is refuted by Frankel (2006) who notes that global investment rates are actually well down on levels seen in the 1980s, a scenario consistent with a US shortfall sucking in capital from the rest of the world.

${ }^{15}$ Britain has similar problems in terms of high consumption levels, low savings and a deteriorating trade deficit. With reduced consumer confidence in 2005, it was hoped that exports would pull up overall growth rates but such export-led growth failed to materialise, partly because of the continuing over-valuation of sterling. The continuing de-industrialisation of the UK economy may have effectively closed off such an export-led growth option anyway, with manufacturing now accounting for well under $20 \%$ of GDP. Rowthorn and Coutts (2004) suggest that such deindustrialisation may have now gone too far. Too much manufacturing capacity may have been shed, and the failure to develop a more dynamic manufacturing sector may have "serious consequences for the balance of payments and prosperity".
} 
Achieving this broader rebalancing requires the recognition that the strategies of Corporate America (interacting with a compliant government) are critical in creating these imbalances and potential instability. Tackling this underlying problem therefore calls for a rebalancing of the industrial base in the US; this is easier to achieve via the use of industrial policy rather than relying solely on macro policy. The latter is anyway very challenging (see Brittan in Financial Times, 21/01/05). Buttressing such macroeconomic measures with an industrial policy aimed at re-balancing would, we suggest, improve the chances of success considerably.

\section{$4 \quad$ Recent Industrial Performance in the US and Europe}

Despite these pressing internal and external imbalances, the United States is often held up as a role model for the rest of the world, both for its record on employment, and for its recent dynamism in terms of GDP and productivity growth. In the macro context we can see demand-side investment as being necessary to achieve this outcome, where the state is constrained. The general retreat from Keynesianism can be expected to induce this sort of capitalist response, in effect trying to replace Keynesian demand management with internal demand management. So-called 'Golden Ages' can thus be seen either as the result of state augmentation of capitalist expenditure or as a "purer" capitalist creation, made out of its own internal mechanism to cure any problem of demand side weakness. The United States is closer to the purer form of capitalism managing itself, at least in a microeconomic sense, but it has also managed to retain a semblance of Keynesian rules, in particular through the operation of a Federal Reserve which has taken a broad view of its role and has emphasised economic growth as well as fighting inflation. In contrast, the EU has in effect abandoned such rules, in particular through the imposition of the Stability and Growth Pact and an excessively restrictive inflation target for an unaccountable European Central Bank. Somewhat perversely, therefore, the United States now has a greater dynamism within its own capitalist system and thus has less need for the state to augment demand, yet in practice it appears less constrained than Europe about such intervention. Meanwhile, because Europe now has less internal dynamism it actually requires more augmentation of 
demand, yet is more constrained given the economic rules it has adopted. Many, including the IMF, are now suggesting that Europe and Japan should take over as demand-side drivers of the global economy, as part of the global rebalancing that is required.

The problems and challenges facing the US and Europe are therefore now quite different. On the one hand, Europe is losing a dynamism it formerly possessed. On the other, the US is creating an enormous international imbalance (related to its internal imbalances) which is increasingly unsustainable. As Blanchard (2004) has noted, this pessimism in Europe is "based on evolutions since the mid-1990s, and the feeling that the US is again gaining advance on Europe". Yet we need to be careful in making sweeping generalisations. The much-acclaimed recent superior performance of the US is, in fact, based on only a few years evidence (since 1995), whereas European performance had been superior over the previous half-century in closing the 'productivity gap'. What would appear to have happened is a slippage in European performance recently, combined with evidence of a US industrial renaissance (Best, 2001). Superior US productivity growth in ICT-using industries has become a particular focus for attention. The key difference in performance recently, between US and Europe, has really been in the service sector (comprising retailing, wholesaling, and financial services). Here there has been a superior performance in labour and total factor productivity growth in US (O'Mahoney and Van Ark, 2003), and the US appears more effectively to have deployed ICT in these sectors in particular. ${ }^{16}$

We suggest that this growth in productivity in US service sectors and the take up of ICT has been connected to the consumer boom in the US described above, in that the banking, retailing and wholesaling sectors have had both the incentive to take up ICT in order to raise productivity in the context of rising demand, and have also had the resources to invest in such ICT. In this sense, the ICT take up and productivity boost is connected with the growth of the imbalances in the US economy. We question whether the superior performance in productivity would have been

\footnotetext{
${ }^{16}$ Annual labour productivity growth over $1995-2001$ in distributive trades was $5.1 \%$ in the US as against $1.0 \%$ in EU15, and in financial services it was $5.2 \%$ in the US as against $2.8 \%$ in EU15 (O'Mahoney and Van Ark, 2003)
} 
observed without the imbalance in demand. In other words, the increase in consumption, fall in savings, and growth in the external imbalance, have fuelled a form of dynamism in the economy. However, as noted, the imbalances are becoming so large that they need to be addressed as a matter of priority and it is unlikely this can be achieved with only macroeconomic adjustment as the imbalances are rooted in the basic structure of the economy. Despite differences in economic performance, there might therefore be a deeper policy convergence between the US and Europe. In the US case, a policy is required that is industrial and macroeconomic, directed at addressing the vulnerable dynamism where that dynamism appears to be linked to enormous external (and internal) imbalances. Meanwhile, the strategies of Corporate Europe are lacking in dynamism and policies are required to stimulate alternative forms of dynamism and that provide a different rebalancing of the industrial base emphasising a new European entrepreneurship which is more able to take an active place in the global new economy. We will discuss below what form such policies might take but before then we need to consider exactly what type of dynamism the US has retained.

\section{$5 \quad$ Revisiting the Dynamics of Capitalism}

In his seminal 1943 volume 'Capitalism, Socialism and Democracy', Schumpeter argued that capitalism (unlike socialism) had a built-in mechanism for growth and dynamism. ${ }^{17}$ This was because capitalist entrepreneurship was fuelled by the constant search for the temporary monopoly profits arising from successful innovation and bringing products to market ahead of rivals. This "perennial gale of creative destruction" involving the creation and destruction of temporary monopoly positions was the driving force of capitalism, he argued, and it was this process which drove up average levels of productivity and prosperity over time. Schumpeter

17 Whilst Schumpeter's work does not fit within the mainstream neo-classical approach, it influenced much of the later work on the innovation process which has become widely accepted. As Petit (1996) noted, there was something of a revival from the 1970s onwards of the Schumpeterian view that innovation is a driving force in market competition. This neoSchumpeterian structuralist tradition includes those such as Nelson and Winter (for example $1974,1982)$ who concentrate on the microeconomics of market developments and others such as Freeman and Soete (for example 1987) who stress the macroeconomics of long term cycles. 
rightly saw Soviet-style top-down socialism as lacking such dynamic tendencies, being centralised, bureaucratic and non-entrepreneurial. ${ }^{18}$

Despite having identified this process of "creative destruction" as the key to understanding what underpins dynamism in capitalism, Schumpeter is perhaps most remembered for his answer to the question he asks in his 1943 volume: "Can Capitalism survive? No. I do not think it can". By this he meant that it would ultimately fail. He identified a number of tendencies which would cause this. Firstly, high levels of prosperity would bring a dwindling demand for new products and processes. Secondly, there would be less need for entrepreneurship and less willingness to tolerate the economic turmoil and insecurity that he felt would accompany material progress. Thirdly, routine bureaucratic management would be all that would be needed in large corporations, and socialism was perfectly able to provide this. The dominance of large corporations, he suggested, would usurp the innovative function of entrepreneurs. All of these tendencies would be reinforced, he argued, by the cultural contradictions inherent in modern capitalism, including the tendency to alienate intellectuals (Hanson, 1990). Indeed, Schumpeter saw the decay of social support for capitalism as critical in his envisaged decline of capitalism. This social-support dimension may have significance in terms of the fusion of the public, private and social spheres that has been witnessed in more decentralised and successful systems such as the Italian industrial districts.

A particular concern for Schumpeter was that the "perfectly bureaucratized giant industrial unit not only ousts the small or medium sized firm and "appropriates" its owners but in the end it also ousts the entrepreneur" (Schumpeter, 1943: 134). Linked to this, the innovative function of entrepreneurs would, he felt, become routinised in the large corporation: "technological progress is increasingly becoming the business of teams of trained specialists who turn out what is required and make it work in predictable ways... economic action tends to become depersonalised and

\footnotetext{
${ }^{18}$ Of relevance here, this Schumpeterian world is dominated by monopoly capitalism, where large corporations are aware of their market power and actively use it. Indeed, Schumpeter expected to see non-price forms of competition such as advertising and even anti-competitive practices such as price-fixing, investment in excess capacity to deter market entry by rivals, or taking over competitors as common place (Coe and Wilber, 1985). His view of what capitalism actually involves seems remarkably prescient today in terms of rivalry between giant firms.
} 
automated. Bureau and committee work tends to replace individual action" (ibid, 132133). For these reasons, Schumpeter felt that "there is inherent in the capitalist system a tendency toward self-destruction which, in its earlier stage, may well assert itself in the form of a tendency towards a retardation of progress", which might be interpreted crudely in terms of a reduction of relative $R \& D$ expenditure over time.

The prevailing wisdom is that Schumpeter 'got it wrong' (see for example Heilbroner, 1981); after all capitalism increasingly dominates the global economy. The analysis above, which explores the forces in modern capitalism, suggests that US style monopoly capitalism in some sectors at least may thus have found a way to overcome the Schumpeterian limits to dynamism through competing via high levels of advertising, thereby forming and reforming demand preferences which in turn leads to rising expenditure (and debt) plus longer hours worked. Such rapid growth in advertising as a way of maintaining demand as prosperity rises was not something that Schumpeter had anticipated despite his recognition of non-price forms of competition.

Others researchers did anticipate such trends in advanced capitalism. Most notably, Sweezy (1972) stressed the tendency of monopoly capitalism to "secular stagnation" and recognised the need for strong counterveiling forces to enable the system to operate at a "politically tolerable" level of production and employment. Such forces, he argued, are generated within the economy, through non-price competition such as advertising and contrived obsolescence; "in this way a huge sales effort... increases the effective demand for goods and services" (ibid: 9). From this perspective, the relative level of "unproductive activity" in advanced capitalism would be expected to rise over time (Baran and Sweezy, 1966). Such an expansion in unproductive activity in the post-war US economy was charted and analysed by Wolff (1987), whose definition of such activity included ruling, warfare, religion and controlling circulation (including the growth of advertising, most notably in the 194758 period). Wolff's estimates for the US suggest that all of the increase in employment in the between 1947 and 1967 was in this unproductive activity, and he found a strong inverse relationship between unproductive activity and net capital formation. Yet Wolff's supply-side work differed sharply with the demand 
management approach of Baran and Sweezy. The latter emphasised the demand management dimension of unproductive expenditures, especially defence, in filling the inevitable slack in effective demand in advanced capitalism, thereby ensuring full employment and stimulating growth, capital formation and productivity growth. In contrast, Wolff looked at the disposition rather than realisation of surplus value, and took the view that unproductive activity decreased the resources available for capital accumulation, thereby slowing productivity and overall growth. Put another way, Wolff (187:22) saw his approach as looking at the damaging dynamic effects of the growth in unproductive activity whereas Baran and Sweezy examined the static implications for demand. As Cowling (2004) notes, Wolff seems to address the symptoms of a deeper malaise whose cure has yet to be identified.

In a sense this paper attempts to provide a bridge between the two approaches, in that we attempt to recognise and link both demand- and supply-side effects. In so doing, we note the demand side effects of 'unproductive activities' such as advertising in boosting demand and see this as having providing a market incentive for certain US service sectors to use ICT, which in turn has had a supply-side effect in raising productivity in those sectors. On the latter, Wolff's approach also has resonance in the sense that monopoly capitalism in the US has retained a type of dynamism through rapidly rising advertising and debt-financed consumption. However, this form of dynamism is, we suggest, flawed or vulnerable (analogous to Wolff's damaged dynamism) because of the scale of the internal and external imbalances built up in the US economy. Rising levels of private debt and the trade deficit are increasingly seen as unsustainable and require changes that go beyond pulling macro-economic levers such as adjustments in interest rates, the fiscal stance or the exchange rate. It is important to recognise that this form of non-price competition, i.e. high levels of advertising expenditure, chosen by monopoly capital is a strategic decision. The strategic decisions to spend such large and increasing amounts of advertising expenditure have been taken by the key decision-makers in the giant enterprises which constitute oligopolistic industries. It is to this which we turn next. 


\section{A Strategic Choice Perspective}

Schumpeter's view that top-down planning in giant corporations was a 'version of central planning' (Samuels, 1985) is a view not dis-similar to that of modern commentators on corporate governance (see Kay, 1997). Similarly, his concern over the dominance of large corporations and their damaging effect in usurping the innovative function of small-scale entrepreneurs has parallels with the concerns raised by those working from the more contemporary strategic choice perspective. Planning was a key aspect of Coase's (1937) theory of the firm, where the latter were viewed as 'islands of planning'. In modern language, this power to control planning can be seen as the power to make strategic decisions over the broad objectives and direction of the firm. Exactly who controls a firm in this way has been the subject of much debate amongst economists: some argue, in line with Berle and Means' (1932) early work, that corporate control remains with (senior) managers, others focus on certain powerful shareholders, whilst others see such groups as basically the same people anyway. Whilst recognising the possibility of 'heterogeneity' across firms in terms of the exact composition of elites, there is a consensus amongst economists that control of firms "rests with a subset of those having an interest in a firm's activities, and certainly does not rest with the workforce. Strategic decision-making is concentrated in the hands of an elite" (Cowling and Sugden, 1999)

Underpinning this approach, a distinction is drawn between 'corporate' and 'community' strategies. 'Corporate' strategies are viewed as strategies for development conceived by and in the interests of strategic decision makers within giant firms, whereas 'community' development strategies are those devised by and in the interests of a wider set of actors in the community (Sugden and Wilson, 2002). The implication is that if strategic decision-making is the preserve of only a few, there arises the potential for 'strategic failure', where the objectives of the elite making strategic decisions conflict with wider interests in society, with the result that the economic system fails to deliver the most appropriate outcomes for the community. The risks of such strategic failure are seen as more likely when deregulation and liberalisation create increased freedom from intervention by government, workers and others (greater 'negative' freedom) for strategic decision-makers in giant firms 
over strategic issues such as advertising and marketing expenditure, investment, research and development, output, employment and so on. As control over such decisions becomes more firmly enshrined in the hands of a few elite decision makers within increasingly dominant and mobile firms, the risks of 'strategic failure' become more likely, with the objectives of the elites making those strategic decisions conflicting with wider interests in society (Cowling and Sugden, 1998, 1999). Precisely because so-called 'free markets' concentrate strategic decision-making in the hands of elites, "development paths based upon an especially prominent role for transnational corporations are inherently problematic" (Cowling and Sugden, 1999).

The implication of this analysis is that the form of non-price competition chosen by monopoly capital, i.e. high and growing levels of advertising expenditure, is in essence a strategic decision taken by such firms. The growth of this form of unproductive activity (expenditure on advertising) used to shape preferences and work-leisure choice is actually determined in a top-down way by concentrated elites of decision-makers in giant firms as an alternative to price competition. This outcome and social waste, whilst providing the stimulus for the adoption of new technologies in service sectors (via high levels of demand), is actually an example of strategic failure, with the internal and external imbalances identified above being the side effects of this strategic decision by elites. Whilst monopoly capitalism may have overcome the Schumpeterian limits to dynamism by such strategic choices by elites of decision makers to increase advertising, this has come at a cost in terms of longer hours worked, rising debt, falling savings, and deeply unbalanced international trade. Industrial policy needs not only to ameliorate these costs but also needs to address the issues that Schumpeter identified sixty years ago; the shift under advanced capitalism from a diffuse, entrepreneurial system of small firms to giant corporations in monopoly capitalism which in turn concentrates decision-making. A deep, structural change in the economy is required in order to tackle this very problem.

\section{Beyond 'Vulnerable Dynamism' through a 'New' Industrial Policy?}

Such a view has implications for public policy at different levels; the multi-national, national and sub-national scales of analysis. It implies that the problem of strategic 
failure is likely to be a real issue for economies in terms of centralised decisionmaking leading to the systemic problems noted above, requiring purposive policy responses both to deal with the consequences and to avoid such failures. ${ }^{19}$ This would require policies to be designed, implemented and assessed in terms of how far they move the economy towards more democratic forms of economic governance (meaning the processes and structures for identifying and making choices over strategy). Facilitating such a radical restructuring of the economy would require a multi-faceted approach, involving the monitoring of the giant transnational firms at the multi-lateral and national level, the development of bottom-up strategies facilitating the participation of wider community groups, the promotion of multilateral small webs (Sugden, 1997, Cowling and Sugden, 1999) as a means of diffusing strategic decision-making as well as a broader conceptualisation of the nature of the free market involving a 'positive' ('the right or ability to') dimension of economic freedom as well as the 'negative' dimension, thereby stressing the role of participatory democracy in strategic decision-making.

Despite much talk of a 'new' industrial policy in the EU and Japan, the emphasis of much economic analysis remains focused narrowly on the fine-tuning of macro-level policies. The thrust of this paper is to suggest that the scale of imbalances built up through the flawed or vulnerable dynamism of advanced capitalism needs much more than such macro-level fine-tuning. In particular, industrial policy needs to be brought centre-stage to economic policy, as an underlying feature of this 'vulnerable dynamism' perspective is the very industrial structure of advanced capitalism. In particular, the concentration of strategic decision making in giant firms has resulted in strategic failure taking a number of forms, including the choice by oligopolistic elites to spend large and increasing amounts on advertising, thereby shaping and reshaping demand preferences.

Macro-level adjustments on trade, the budget and consumption and investment are necessary (but, we argue, not sufficient) in terms of overcoming such imbalances. Such adjustments do represent an important aspect of providing a temporary and short-term macro-level rebalancing of the economy. Indeed, the concentrated

${ }^{19}$ Of course, it cannot be assumed that state intervention will improve matters as the latter could be used by powerful corporations to further their own interests (Cowling and Sugden, 1999) 
industrial structure cannot anyway be dismantled without losing a form of dynamism (albeit vulnerable), which would impact on productivity and overall growth. As Cowling (2004) notes, simply holding back on the 'unproductive activities' that Wolff (1987) identified, such as advertising, the law and war, does not in itself guarantee a more dynamic economy. Rather, alongside short-term macro responses, more longterm and deep-rooted structural reforms are required to the industrial structure so as to shift the structure of the economy from monopoly capitalism to a more diffuse pattern of strategic decision making, which could unleash alternative sources of dynamism.

A number of policy issues flow from this analysis and whilst beyond the scope of this paper to go into detail, it is important that we identify their broad direction and relevance so as to stimulate a more fruitful debate. The first objective of policy should be to broaden strategic decision making so as to avoid strategic failure. This would involve a 'dual approach' which works within the shadow of the dominant regime to ameliorate the most corrosive effects of strategic failure whilst simultaneously building a more positive and dynamic form of capitalism built around small firm webs. ${ }^{20}$ For example, in recognising the dominance of giant firms, certain 'negative' restraints such as limits on the level and form of advertising, as well as mergers, may be appropriate. However, it should be noted at the outset that such negative restraints have a specific and limited role for two reasons. Firstly, they will be vigorously opposed by the dominant corporations. Secondly, powerful firms will find ways around such advertising restraints, as may be observed in the pharmaceutical sector. Overall, given the entrenched power of monopoly capitalism, we need to recognise the limits of what such 'negative' restraints might achieve.

Nevertheless, innovative 'negative' policies that attempt to shift away from concentrated or elite decision-making may be relevant. In the US case, an interesting possibility has been suggested by Medlen (2005), who notes that over the last thirty years the excess cash of US corporations approximates the negative saving gap in the non-corporate sector. ${ }^{21}$ He suggests raising taxes to claim back the

\footnotetext{
${ }^{20}$ This is similar to the 'dual approach' to development suggested by Sugden and Wilson (2002).

21 Leaving aside the issue of whether households can actually "pierce the corporate veil", household and corporate savings decision are linked (see IMF, 2006).
} 
'free cash' of US corporations and redirecting the cash towards the savinginvestment gap of the non-corporate sector, such as into housing, mass transit or the small business sector. This could have the benefits of maintaining aggregate demand, curbing wasteful and speculative expenditure by corporations on takeovers, encouraging the development of small firms and reducing the cost of housing, thereby freeing up household resources for expanded saving.

Beyond this, more positive 'bottom-up' measures are required in terms of proactively growing a more diffuse system of entrepreneurship that fuses the public and private, and avoids the risk of strategic failure. This should be the broad strategic goal towards which a range of new policies need to be developed and coordinated. Crucially, this would require policymakers moving beyond the Porterian view of 'clusters' and 'cluster policy' - which has been both superficial in its analysis and confused in its policy-relevance (Martin and Sunley, 2003) - towards a more sophisticated and detailed understanding of relationships within and across different 'clusters', focusing in particular on the governance structures required in order to avoid 'top down' concentrated strategic decision-making and strategic failure. Building webs of small firms, where strategic decision making is more diffuse, should be a focus for policy, initially by encouraging existing local production systems to look outwards to other systems, and then to build multi-locality webs underpinned by mental proximity. Multi-locality webs are seen as a potential alternative to the topdown control of giant firms, and would be large-scale production processes comprising a myriad of smaller firms in a nexus of criss-crossing relationships which span borders - in other words, multi-local (rather than a transnational controlled) production processes (Sugden, 1997, Cowling and Sugden, 1999). Lessons might be learned from experience elsewhere; in order to compete internationally without the economies of scale that transnationals enjoy, firms in certain industrial Italian districts have cooperated in the collective provision of marketing and other services. Such cooperation amongst enterprises could be encouraged and enhanced through the provision of support structures and quasi-public goods to webs of small firms. These could include specialist services and R\&D support, for example via more innovative university-web-community relationships. The latter would have to be underpinned by a re-appraisal of the role of universities and a shift away from the on- 
going corporatisation of higher education towards conceptualising universities as providing a counterpoint to corporate hegemony. This would require a new sort of University, 'urbi et orbi': integrated in the industrial economy, based in the locality, but looking out, developing a multi-national base. Similarly, the finance system would need to be shifted towards a more decentralised form with the dominant objective of supporting webs of small firms rather than giant capital.

Positive policy experiences also need to be drawn on in developing new approaches, whilst recognising the inappropriateness of simply transplanting policies without recognising social and cultural differences. As noted, despite the need for greater public intervention in Europe given its lack of dynamism, government intervention in the United States has been much more active and creative than is generally appreciated. This can be seen in terms of government funding for R\&D via the university system. In addition there has been the use of a hidden but de facto industrial policy via the Pentagon and other areas of government in terms of the procurement and stimulation of high-technology products over many years, including computers, aerospace and semi-conductors (Geroski, 1990) and more recently dualuse flat-screen technologies (US Congress, 1995). As Geroski notes, in the case of the computer industry, such government action "almost single handedly brought into being what has now become an enormous commercial market". Furthermore, this de facto industrial policy of targeting new technologies with widespread civilian spillovers has included the use of 'second sourcing' to deliberately stimulate a diffuse, competitive industry, rather than simply placing orders with giant firms (Geroski, 1990). Other areas of intervention include the more generic use of taxcredits to subsidise 'private sector' innovation (Hall and Van Reenan, 2000), extensive government support for venture capital (Lerner, 1999) and an ongoing willingness to question the value and effects of inward foreign direct investment. On the latter, elements of the Bush administration post 9/11 have sought to extend the definition of 'national security' to protect high technology sectors such as telecommunications and the internet from foreign takeovers (Bailey, 2003).

Overall, there has been quite extensive public policy intervention in the United States, but this is often opaque and hidden. This industrial policy has involved both 
vertical measures in targeting new technologies and emerging industries, and horizontal measures to support all industries, suggesting that the current focus in Britain and the EU with the horizontal aspects of industrial policy has been largely misplaced (Bailey and Driffield, 2006). Similarly, Japan is also trying to encourage the take-up of new technologies by service sectors and the development of new strategic industries. The combination of horizontal and vertical/sectoral measures being developed in its "new industrial policy" has led some commentators to suggest that Japan is "revisiting the famous government-industry collaboration that served them so well in earlier decades" (Genther Yoshida, 2004). This may have relevance in the European context, given the desire to re-activate the EU's 'Lisbon agenda'. If European leaders want to improve the EU's dynamism in using ICT in services, there might be useful lessons to be taken from Japanese experience in terms of how new ICTs were spread to users via the Japanese Computer Company from the 1960s onwards (Anchordoguy, 1988). ${ }^{22}$

\section{Concluding Comments}

Despite much talk of a 'new' industrial policy, the emphasis of much economic analysis remains focused narrowly on the fine-tuning of macro-level policies. The thrust of this paper is to suggest that the scale of imbalances built up through the flawed or vulnerable dynamism of advanced capitalism needs much more than such macro-level fine-tuning. In particular, industrial policy needs to be brought centrestage to economic policy, as an underlying feature of this 'vulnerable dynamism' perspective is the very industrial structure of advanced capitalism. In particular, the concentration of strategic decision making in giant firms has resulted in strategic failure taking a number of forms, including the choice by oligopolistic elites to spend large and increasing amounts on advertising, thereby shaping and re-shaping demand preferences and boosting demand. Whilst bringing benefits in the United States in terms of overcoming Schumpeterian limits to growth and driving productivity growth via the use of ICT in service industries, this has come at a great

\footnotetext{
${ }^{22}$ The debate on why an ICT-inspired productivity pick-up has not occurred yet in the EU, in contrast to the US, is on-going. One view is that there is a lagged effect, in that the US invested first in ICT, and saw productivity gains after only 15 years, whereas the EU invested much later and has yet to see a return (see O'Mahoney and Van Ark, 2003).
} 
cost, viewed here as a form of strategic failure, in terms of longer hours worked, rising debt, falling savings and pension provision, and deeply unbalanced international trade. Such internal and external imbalances are increasingly unsustainable.

Macro-level adjustments on trade, the budget and consumption and investment are therefore necessary (but, we argue, not sufficient) in terms of overcoming such imbalances in the US. Alongside these short-term macro responses more long-term and deep-rooted structural reforms are required to the industrial structure so as to shift the structure of the economy from monopoly capitalism to a more diffuse pattern of strategic decision making, which could unleash alternative sources of dynamism. Given that the strategies of Corporate Europe are lacking such dynamism, a different rebalancing of the industrial base is required that emphasises a new European entrepreneurship (which in turn is more able to take an active place in the global new economy). In so doing, there is a need to emphasise the development of creative clusters of small firms, displacing less dynamic corporate giants, and to diffuse strategic decision making across a wider variety of actors. Taken together, these could enable a deep, structural change away from the dominance of giant corporations in modern capitalism to a diffuse, entrepreneurial system of small firms, and might address the very problem that pre-occupied Schumpeter sixty years ago.

\section{References}

Anchordoguy, M. 1988. Mastering the Market: Japanese Government Targeting of the Computer Industry. International Organization.

Bailey, D. 2003. US Policy Toward Inward FDI: CFIUS and Extension of the Definition of 'National Security'?, The Journal of World Investment, Vol.4, Iss.5.

Bailey, D and N Driffield. 2006. Industrial Policy, FDI and Employment: Still 'Missing a Strategy', Journal of Industry, Competition and Trade, forthcoming, 2006.

Bailey, D, G Harte and R Sugden. 1994. Making Transnationals Accountable. London: Routledge.

Baran, P and P Sweezy. 1966. Monopoly Capitalism. An Essay on the American Economic and Social Order. New York: Monthly Review Press.

Bell, $L$ and R Freeman. 2001. The Incentive for Working Hard: Explaining Hours Worked Differences in the US and Germany, Labour Economics, Volume 8, Iss 2, May.

Berle, A A and G C Means. 1932. The Modern Corporation and Private Property. Basingstoke: Macmillan, 1932.

Best. M. 2001. The New Competitive Advantage.

Blanchard, O, 2004. The Economic Future of Europe, National Bureau of Economic Research Working Paper, No. 10310. Washington DC: NBER. 
Blanchflower, D and A Oswald. 2004. Well-Being over Time in Britain and the USA, Journal of Public Economics, Vol.88, 1359-86.

Bonner, B and A Wiggin. 2005. Empire of Debt: The Rise of an Epic Financial Crisis. Hoboken, NJ: John Wiley.

Brack, J and K Cowling. 1983. Advertising and Labour Supply: Work Week and Work Year in US Manufacturing 1919-1976, Kyklos, 285-303.

Business Week. 2004. 'At P\&G it's a "360-Degree Innovation"', 11/10/04.

Capital. Why Aren't we Saving More? 05/03/06: B3.

Coase, R H. 1937. The Nature of the Firm, Economica, Vol. 4.

Coe, R and C Wilber. 1985. Schumpeter Revisited: An Overview, in R Coe and C Wilber, Ed.s, Capitalism and Democracy: Schumpeter Revisited. Notre Dame: University of Notre Dame Press.

Cowling, K. 2004. Monopoly Capitalism and Stagnation, in Tracy Mott and Nina Schapiro, Ed.s, Rethinking Capitalist Development. London: Routledge.

Cowling, K and R Poolsombat. 2005. Advertising and Labour Supply: Why do Americans Work Such Long Hours? Mimeo: Department of Economics, University of Warwick. 2006. Prosperity, Depression and Modern Capitalism, Kyklos, Vol.59, Iss.3.

Cowling, K and R Sugden. 1994. Beyond Capitalism. Towards a New Economic Order. London: Pinter.

1998. Strategic Trade Policy Reconsidered: National Rivalry vs Free Trade vs International Cooperation, Kyklos, Vol.51, Fasc.3, 339-357.

1999. The Wealth of Localities, Regions and Nations: Developing Multinational Economies, New Political Economy, Vol.4, No.3.

Cowling, K and P Tomlinson. 2005. Globalisation and Corporate Power, Contributions to Political Economy, Vol.24, 33-54.

The Daily Telegraph. 2004. Drugs Firms are Scaring People for Profit, 12/11/04.

Daripa, A And S Kapur. 2001. Pricing on the Internet, Oxford Review of Economic Policy, Vol.17, Iss.2.

Duesenberry, J S. 1967. Income, Saving and the Theory of Consumer Behaviour. Oxford: OUP.

El-Ayd, A, R Barrell, and O Pomerantz. 2005. Correcting US imbalances, National Institute Economic Review, April 2005 issue.

Euromonitor. 1999. Global Market Information Database. London: Euromonitor.

Frankel, J. 2006. Could the Twin Deficits Jeopardize the US Hegemony?, American Economics Association Meeting, January 2006. Forthcoming in Journal of Policy Modelling.

Fraser, S and Paton, D. 2003. Does Advertising Increase Labour Supply? Time Series Evidence for the UK, Applied Economics, Vol.35, No.11, 1357-1368.

Freeman, C and L Soete. 1987. Technical Change and Full Employment. Oxford: Basil Blackwell.

Galbraith, J K. 1958. The Affluent Society. New York: Houghton Mifflin.

Genther Yoshida, P. 2004. Japan's "New" Industrial Policy Revives Old Successful Ways, Research Technology Management, Vol.47, Iss.6.

Geroski, P. 1990. Encouraging Investment in Science and Technology, in K Cowling and R Sugden, Eds, A New Economic Policy for Britain.

Godley, W, D Papadimitriou, C Dos Santos and G Zezza. 2005. The United States and her Creditors: Can the Symbiosis Last? Bard College: The Levy Economics Institute of Bard College.

The Guardian. 2004. Big Pharma's Tiny Gestures, 21/03/04.

Huxley, A. 1932. Brave New World. New York: Harper \& Brothers.

Financial Times. 'Why l'm with the Wild-Eyed Protesters over P\&G's Deal', 01/02/05.

------ , 'A Heretical View on the Dollar', 21/01/05. 
Hall, B and J Van Reenan. 2000. How Effective are Fiscal Incentives for R\&D? A Review of the Evidence, Research Policy, 29, 449-469.

Hanson, P. 1990. Ownership Issues in Perestroika, in J. Tedstrom, Ed., Socialism, Perestroika and the Dilemmas of Soviet Economic Planning. Boulder: Westview Press.

House of Commons. 2005. Fourth Report of the Select Committee on Health: The Influence of the Pharmaceutical Industry. London: The Stationery Office.

IMF. 2006. World Economic Outlook. Washington DC: IMF.

Kay, J. 1997. The Stakeholder Corporation. In G. Kelly, D. Kelly and A. Gamble, ed.s, Stakeholder Capitalism. Basingstoke: Macmillan.

Lerner, J (1999) "Public Venture Capital": Rationales and Evaluation, in STEP (US Government Board on Science, Technology, and Economic Policy), The Small Business Innovation Research Program: Challenges and Opportunities. Washington DC: National Academy Press.

$\mathrm{Li}$, H. 2002. Advertising Media, in Encyclopedia of Advertising. Chicago, II: Fitzroy Dearborn.

Lomax, R. 2006. Global Financial Imbalances, Chatham House Conference on Global Financial Imbalances, London, January 2006. www.bis.org/review/r060127f.pdf

Martin, R and P Sunley, 2003. Deconstructing Clusters: Chaotic Concept or Policy Panacea? Journal of Economic Geography, Vol.3, Iss.1, 5-35.

Medlen, C. 2005. Two Sets of Twins? An Explanation of Domestic Imbalances, Journal of Economic Issues, Vol.39, Iss.3.

Mishel, $\mathrm{L}$ and $\mathrm{R}$ Eisenberry. 2005. What's Wrong with the Economy? EPI Policy Memorandum, 21/12/05. Washington DC: Economic Policy Institute.

Nelson R and S Winter. 1974. Neoclassical vs Evolutionary Theories of Economic Growth, The Economic Journal, 84, 886-905.

----- 1982. An Evolutionary Theory of Economic Change. Cambridge, MA: Belknap Press.

Obstfeld, M and K Rogonoff. 2004. The Unsustainable US Current Account Position Revisited, National Bureau of Economic Research Working Paper, No. 10869. Washington DC: NBER.

OECD. 1999. Main Science and Technology Indicators. Paris: OECD.

O'Mahoney, M and B Van Ark. 2003. EU Productivity and Competitiveness: An Industry Perspective. Can the EU Regain the Catching-up Process? Luxembourg: European Commission.

Petit, P. 1996. Employment and Technological Change, in P Stoneman, ed, Handbook of the Economics of Innovation and Technological Change. Oxford: Blackwell.

Prescott, E C. 2004. Why do Americans Work so Much More than Europeans? Federal Reserve Board of Minneapolis Quarterly Review, Vol.28, Iss.1, July.

Rowthorn, R and K.Coutts. 2004. De-Industrialisation and the Balance of Payments in Advanced Economies, Cambridge Journal of Economics, Vol.28, No.5.

Ruggles, R. 1993. Accounting for Saving and Capital Formation in the United States 1947-1991, Journal of Economic Perspectives, 3-17.

Samuels, W. 1985. A Critique of Capitalism, Socialism and Democracy, in R Coe and C Wilber, Ed.s, Capitalism and Democracy: Schumpeter Revisited. Notre Dame: University of Notre Dame Press.,

Schumpeter, J A. 1943. Capitalism, Socialism and Democracy. London: Henderson and Spalding.

Smiley, R. 1988. Empricial Evidence on Strategic Entry Deterence, International Journal of Industrial Organisation, Vol.16. 
Sugden, R and J R Wilson. 2002. Economic Development in the Shadow of the Consensus: A Strategic Decision Making Approach, Contributions to Political Economy, Vol 21.

Sweezy, P. 1974. Modern Capitalism and other Essays. New York: Monthly Review Press.

Taylor, L D and D Weiserbs. 1972. Advertising and the Aggregate Consumption Function, American Economic Review, September.

TNS Media Intelligence, 2005. US Advertising Market Shows Strong Growth in 2004. http://www.tns-mi.com/news/03082005.htm

The New York Times. 2005. Pleasure of Greed Haunts US. 19/03/05.

US Census Bureau. 2000. Statistical Abstract of the United States: 2000. Washington DC: US Government Printing Office.

US Congress, Office of Technology Assessment. 1995. Flat Panel Displays in Perspective. Washington DC: US Government Printing Office.

Wybrow, P.C. 2005. American Mania: When More is not Enough. New York: W W Norton \& Co.

Wolff, EN. 1987. Growth, Accumulation and Unproductive Activity: An Analysis of the Postwar US Economy. Cambridge: CUP

Yoo, I. 1998. Is Increasing Wealth a Substitute for Saving? National Economic Trends, February 1998. San Francisco: San Francisco Federal Reserve Board.

ZenithOptimedia. 2006. Demand for Traditional Advertising Firm; Internet up Again. London: ZenithOptimedia. 